Sanyaolu, W.A., Adejumo, B.T., \& Kadiri, I. (2020). Board diligence and financial performance: evidence from Nigerian Deposit Money Banks. Copernican Journal of Finance \& Accounting, 9(3), 145-160. http://dx.doi.org/10.12775/CJFA.2020.017

\author{
Wasiu Abiodun Sanyaolu* \\ Crescent University, University of Benin \\ Babatunde Titus Adejumo** \\ Osun Debt Management Office in Osogbo \\ IDRIS KADIRI $^{* * *}$ \\ University of Benin
}

\title{
BOARD DILIGENCE AND FINANCIAL PERFORMANCE: EVIDENCE FROM NIGERIAN DEPOSIT MONEY BANKS
}

Keywords: board meetings, profitability, GMM.

J E L Classification: G20, G21, G33.

Abstract: The study examined the effect of board diligence on financial performance of deposit money banks (DMBs) listed on the Nigerian Stock Exchange. Data of the 10 selected DBMs were obtained from their annual financial statements from 2012 to

Date of submission: September 9, 2020; date of acceptance: October 4, 2020.

* Contact information: abbeysanyaolu15@yahoo.com, Department of Accounting, Crescent University, Abeokuta, Ogun State, Nigeria; PhD Candidate, Department of Accounting, University of Benin, Benin City, Edo State, Nigeria, phone: 08161750742; ORCID ID: https://orcid.org/0000-0002-0695-1961.

** Contact information: babatundeadejumo@yahoo.com, Director-General, Osun Debt Management Office, Abere, Osogbo, Osun State, Nigeria, phone: 08103341511; ORCID ID: http://orcid.org/0000-0002-1272-3746.

*** Contact information: enoch.kadiri@gmail.com, PhD Candidate, Department of Accounting, University of Benin, Benin City, Edo State, Nigeria, phone: 08037190430; ORCID ID: http://orcid.org/0000-0003-3234-6965. 
2018 using an ex post facto research design and purposive sampling technique. The data were analysed using inferential statistics and the hypothesis was tested using Generalised Method of Moment (GMM). It was found that board diligence has significant negative effect on financial performance of Nigerian listed DBMs. As regards the controlled variables, only capital adequacy and firm size were found to positively and significantly influence financial performance. Liquidity ratio was found to have direct but no significant effect on financial performance while nonperforming loan negatively and insignificantly affect financial performance. The study concludes that board diligence reduces financial performance. It is therefore recommended that preference should be given to the quality of board meetings and not the frequency of such meetings; and that issues that have implications on performance should be given utmost attention at board meetings.

\section{INTRODUCTION}

The consequential impact of the global financial crisis of 2007-2008 that hard hit global economy on the banking sector have highlighted the need for a more controlled operational environment, increased governance complexity and calls for effective monitoring by banks' board of directors (Körner, 2017). A unique corporate governance mechanism is a manifestation of dominant role of board of directors on performance and risk-taking behavior (Elyasiani \& Zhang, 2015; Faleye \& Krishnan, 2017). It is the expectation of both the shareholders and regulators that boards should establish an effective risk monitoring system so as to eradicate corporate misconduct and excessive risk taking (Kress, 2018). One of the ways by which the board discharges its monitoring and controlling responsibility is through board meetings. According to Jensen (1993), board meeting and its frequency are regarded as tools for enhancing the monitoring activity of directors, and it has implication on performance. Board meetings are unique component of board supervisory function as outstanding issues and potential solutions relating to an entity are discussed at the meeting. It is thus being regarded as an essential component of good governance (Vafeas, 1999; Conger, Finegold \& Lawler III, 1998; Lipton \& Lorsch, 1992). Eluyela, Akintimehin, Okere, Ozordi, Osuma, Ilogho and Oladipo (2018) regards board meetings as avenue for effective coordination of opinions for attainment of firms' goals and objectives.

According to Kakanda, Bello and Abaa (2016), business survival and growth is a reflection of corporate performance. Marn and Romauld (2012) relate company's performance to its efficient and effective utilization of its scarce resources to accomplish its goals. Corporate performance is majorly measured 
by the ability of company's directors to maximize the wealth of the shareholders. Corporate financial performance is often measured in terms of profitability. Profitability is conceptualized by Gatsi, Gadzo and Akoto (2013) as the final outcome of firms' financing and investing activities, and as well as how management is able to optimize profitability via capital structure decision. Profitability is commonly measured by five indices namely: return on asset, return on equity, return on capital employed, gross profit margin and net profit margin (Ilaboya, 2008).

In Accounting and finance literature, the nexus between board meetings' frequency and financial performance has engendered series of arguments. Basically, there exist two schools of thoughts on the relationship. The first school of thought relates to those who are of the view that board in the fulfilment of its functions of setting strategy and monitoring of management requires frequency of board meetings (Vafeas, 1999).This argument can be supported by the expected role of board meetings in reducing agency problem through the provision of avenue for monitoring and control which will assist in aligning the interest of the managers with that of shareholders. On the contrary, the second school of thought are those that argued that board frequent meetings result to wasting management time and efforts, and waste of company's scarce resources by placing financial burden such as travelling expenses and sitting allowance to directors on the company They conclude that it is the quality of meetings that improve performance and not the quantity (Ntim \& Osei, 2011; Taghizadeh \& Saremi, 2013; Oyerinde, 2014).

Nigeria banking sector provides a pertinent background for investigation of board diligence and financial performance for considerable number of reasonsfirst, the Nigerian banking sector serves as the fulcrum for other sectors of the economy as it provides the finance needed by them. This it does by mobilizing funds from surplus to deficit ends. Thereby, facilitating production, trade and capital formation that resulted in sustainable job creation, and economic development. Second, the sector currently accounts for about $32 \%$ of the entire market capitalisation on the Nigerian Stock Exchange. This further emphasises the significance of the sector in the country. Studies aimed at ensuring sustainability of the sector's current status are therefore considered worthwhile.

Prior literatures in the Nigerian context have majorly focused corporate governance and financial performance in general (Umar \& Sani, 2020; Oyedokun, 2019; Ilaboya \& Obaretin, 2015). The relationship between board meetings and financial performance has not been given the required attention in 
Nigeria, particularly in the banking system. As observed, the only recent study that specifically addressed the issue of board meetings and financial performance in the country's banking system is that done by Eluyela et al. (2018). Whereas, the referenced study provides a good head start, some gaps are however observed in the work. First, the data employed in the study span from 2011 to 2016. This is considered not expansive enough and requires more ampleness. Second, the study views the nexus between board meetings and financial performance from static perspective using regression analysis, third, most variables that are likely to influence profitability other than board meetings (such as liquidity, non-performing loan and capital adequacy) were not included in the study's model. This may produce contentious results and thus; necessitates a re-examination. This paper therefore investigates board diligence and financial performance of Nigerian DBMSs from 2012 to 2018 using GMM on a model that incorporates other predictor variables.

\section{LITERATURE REVIEW}

\section{Conceptual review}

\section{Board meetings and financial performance}

Board diligence in this study is a proxy for board meeting. Board meeting is an important component of corporate governance as it provides an avenue for directors on the board to deliberate on various corporate issues and make strategic decisions that are germane to the success of a company and attainment of its overall objectives. According to Eluyea et al. (2018), regular board meeting is an internal issue which is at the discretion of chairman of board. This is so given that there is no explicit governance law stipulating the maximum number of meetings. Whereas, most governance codes usually indicate minimum of four board meetings per annum without any threshold on the maximum time such meetings can be held, the relationship between frequencies of board meetings on companies' financial performance remains debatable. Empirical studies on board meetings and financial performance have produced conflicting evidences. While a strand of the studies found evidences for positive relationship between board diligence and finance performance (Eluyera et al., 2018; Ntim \& Osei, 2011; Irshad \& Ali, 2015), other studies hold the view that the relationship between them are negative (Johl, Johl, Subramaniam \& Cooper, 
2013, Amran, 2011). According to Chorsch and Maclver (1989) cited in Ilaboya and Obaretin (2015), board meetings frequency is discouraged as it is believed to engender waste in the use of organization resources on activities that are counterproductive.

\section{Theoretical framework}

The popular agency theory is the relevant theoretical framework for this study. The agency problem is the outcome of separation of ownership from management. This occurs where agents (managers) are appointed by principals (shareholders) to run and manage the business on their behalf. As principals are unable to directly observe the behaviour of agents, there arises conflict of interest where managers are tempted to pursue their own self-aggrandizing goals as against those of their principals. According to Eluyela et al. (2018), the agents are appointed and corporate governance mechanism instituted so as to ensure creation of a disciplined atmosphere, setting of timely and achievable strategic plan and effective control of the management so as to maximize shareholders wealth through improved financial performance. Ntim and Osei (2011) argued in favour of regular board meetings indicating that such meetings enhance board advisory, controlling and monitoring capacities and thus ensure discipline so as to improve organizational performance.

\section{Empirical review and development of hypothesis}

Eluyela et al. (2018) using fixed effect regression on data of 15 sampled DBMs from 2010 to 2016 found among others that board meetings has positive insignificant effect on financial performance. Hanh, Ting, Kweh and Hoanh (2018) selecting 94 firms quoted in Ho Chi MinhStock Exchange from 2013 to 2015 found that board meetings negatively affect profitability. Araoye and Olatunji (2019),on the investigation of board meetings and financial performance of 15 selected insurance companies from 2006-2017 found evidence for negative and insignificant effect of board meetings on financial performance. Urhoghide and Omolaye (2017) found that board diligence has no significant positive effect on profitability of oil and gas companies in Nigeria. Akpan (2015) using data of 79 quoted Nigerian companies from 2010 to 2012 and using regression analysis also reveals that board meetings, directors` equity and board size are 
negatively significant on profitability. Other findings from the referenced study are that Audit committee meetings are positively significant, while gender diversity and board age are not significant on profitability (measured by ROE). Al-Daoud, Saidin and Abidin (2016) using GMM on data of 118 listed Amman companies from 2009-2013 found that board meetings positively influence profitability. In contrast, Johl, Kaur and Cooper (2015) focusing on 700 listed companies in Malaysia for 2009 found that board diligence has negative effect on performance. Ilaboya and Obaretin (2015) reported positive insignificant influence of board diligence on financial performance of Nigerian quoted food and beverages companies. Emanating from the mixed findings from the studies mentioned is the formulation of this study's hypothesis as:

$\mathbf{H}_{\mathbf{0 1}}$ : Board diligence has no significant effect on financial performance of $\mathrm{Ni}$ gerian DBMs.

\section{METHODOLOGY}

\section{Sample}

10 DBMs represent the study's sample. 15 DBMS were listed on the Nigerian Stock Exchange. The 10 banks were purposively selected while an ex post facto research design was used.

\section{Source of data}

Secondary data obtained from the annual reports and accounts of the sampled bank were utilized.

\section{Measurement of variables}

The only dependent variable is financial performance which is measured by ROA. This is defined as the proportion of profit after tax to total asset. Several researchers like Sanyaolu, Siyanbola, Gbadebo and Makinde (2019) have proxied profitability by ROA in their study. One independent variable is used by the study as a surrogate for board diligence. This is the number of meetings held in an accounting year by the directors on the board. Furthermore, four variables are used as control variables. These variables are believed to be potential de- 
terminants of ROA. They are: capital adequacy which is measured as proportion of equity capital to total asset, loan to deposit ratio which is measure as the ratio of bank loan to total asset, non-performing loan ratio which is the proportion of non- performing loan to total loan and bank size which is the natural logarithm of banks' total asset.

\section{Method of data analysis}

The analyses of the study involve descriptive, correlation and generalized methods of moment. The GMM is appropriate when the number of observations exceed time series. The statistical package employed for the study is E-views 9.

\section{MODEL SPECIFICATION}

$$
\mathrm{Y}=\mathrm{F}(\mathrm{X})
$$

Where

$\mathrm{Y}=$ financial performance

$\mathrm{X}=$ board diligence

$$
\mathrm{ROA}=\mathrm{F}(\mathrm{BD}, \mathrm{CAR}, \mathrm{LDR}, \mathrm{NPLR} \& \mathrm{FSZ})
$$

$$
\mathrm{ROA}_{\mathrm{it}}=\beta_{0}+\beta_{1} \mathrm{ROA}_{\mathrm{it}-1}+\beta_{2} \mathrm{BD}_{\mathrm{it}}+\beta_{3} \mathrm{CAR}_{\mathrm{it}}+\beta_{4} \mathrm{LDR}_{\mathrm{it}}+\beta 5 \mathrm{NPLR}_{\mathrm{it}}+\beta 6 \mathrm{FSZ}+\mathrm{e}_{\mathrm{it}}
$$

Where;

$\mathrm{ROA}_{\mathrm{it}}=$ return on asset of firm $\mathrm{i}$ in period $\mathrm{t}$;

$\mathrm{ROA}_{\mathrm{it}-1}=$ previous year return on asset of firm $\mathrm{i}$ in period $\mathrm{t}$;

$\mathrm{BD}_{\mathrm{it}}=$ board diligence of firm $\mathrm{i}$ in period $\mathrm{t}$;

$\mathrm{CAR}_{\text {it }}=$ capital adequacy ratio of firm i in period t;

$\mathrm{LDR}_{\mathrm{it}}=$ loan to deposit ratio of firm i;

$\mathrm{NPLR}_{\mathrm{it}}=$ nonperforming loan ratio of firm i in period t;

$\mathrm{SZ}_{\mathrm{it}}=$ firm size of firm $\mathrm{i}$ in period $\mathrm{t}$;

$\beta_{0}=$ intercept term;

$\beta_{1-} \beta_{4}=$ regression coefficient of the independent variable;

$\mathrm{e}_{\mathrm{it}}=$ stochastic error term. 


\section{DESCRIPTIVE STATISTICS}

Table 1. Descriptive Statistics

\begin{tabular}{|l|c|c|c|c|c|c|}
\hline \hline & ROA & BD & CAR & LDR & NPLR & LASSET \\
\hline \hline Mean & 0.017003 & 6.228571 & 0.126438 & 0.699504 & 0.076550 & 20.98964 \\
\hline Median & 0.015478 & 5.500000 & 0.138145 & 0.703721 & 0.037300 & 21.04478 \\
\hline Maximum & 0.119833 & 11.00000 & 0.803866 & 1.277526 & 0.970000 & 22.44036 \\
\hline Minimum & -0.105138 & 4.000000 & -0.607458 & 0.090703 & 0.010000 & 17.87634 \\
\hline Std. Dev. & 0.026249 & 2.001242 & 0.144500 & 0.194458 & 0.129430 & 0.959320 \\
\hline Skewness & -0.840209 & 0.895472 & -1.131955 & -0.071494 & 5.085210 & -0.763573 \\
\hline Kurtosis & 11.91711 & 2.943950 & 19.56902 & 3.959868 & 33.94428 & 3.464079 \\
\hline Jarque-Bera & 240.1542 & 9.364313 & 815.6680 & 2.746896 & 3094.542 & 7.111902 \\
\hline Probability & 0.000000 & 0.009259 & 0.000000 & 0.253232 & 0.000000 & 0.028554 \\
\hline Sum & 1.190179 & 436.0000 & 8.850659 & 48.96525 & 5.358500 & 1406.306 \\
\hline Sum Sq. Dev. & 0.047542 & 276.3429 & 1.440747 & 2.609150 & 1.155902 & 60.73950 \\
\hline Observations & 70 & 70 & 70 & 70 & 70 & 70 \\
\hline \hline
\end{tabular}

S o u r c e : authors computation (2020) using E-view 9.

The table above shows the statistical attributes of the variables of the study. ROA is averaged 0.017 with a minimum of -0.105 and maximum of 0.12 . Board diligence has a mean value of 6.2 and ranges from 4 to 11 . Capital adequacy ratio is averaged $12.6 \%$ and varies from $-60.7 \%$ to $80.3 \%$. Loan to deposit ratio is averaged $70 \%$ with a minimum of $9.1 \%$ and maximum of $128 \%$. Nonperforming loan ratio has a $7.7 \%$ and ranges from $1 \%$ to $0.97 \%$. Size has an average value of 20.98964(log inverse) and varies from 17.87634 to 22.44036 . As to the normality of the variables all but loan to deposit ratio are normally distributed as the probabilities of their Jarque-Bera are significant at 5\%. As to the kurtosis, only Board diligence is found to be platykurtic as the value is below the threshold of 3 while all others are leptokurtic. 


\section{Correlation analysis}

Table 2. Correlation Matrix

\begin{tabular}{|c|c|c|c|c|c|c|}
\hline \hline & ROA & BD & CAR & LDR & NPLR & SIZE \\
\hline \hline ROA & 1.000000 & & & & & \\
\hline BD & -0.143007 & 1.000000 & & & & \\
\hline CAR & 0.772339 & -0.096595 & 1.000000 & & & \\
\hline LDR & 0.083054 & 0.187795 & 0.041841 & 1.000000 & & \\
\hline NPLR & -0.099053 & -0.026266 & 0.075893 & 0.296981 & 1.000000 & \\
\hline SIZE & 0.322073 & 0.204254 & 0.061189 & 0.142097 & -0.126410 & 1.0000 \\
\hline \hline
\end{tabular}

S o u r c e : authors computation (2020) using E-view 9.

The table above shows the correction among all the variables of the study. As it is shown above, none of the variables has a correlation coefficient in excess of 0.80 . As such, there is no problem of auto correlation.

\section{Result}

The adjusted R-Square of 0.636 implies that almost $64 \%$ variation in profitability is explained by the dependent and control variables included in the study's model. This indicates the level of precision of the model. The J-statistics value of 46.0 with corresponding probability of 0.000 implies that the model as a whole is statistically significant at $1 \%$ level of significance. The Durbin Watson value of 1.827 shows that there is no problem of autocorrelation. We found that last year profitability does not significantly drive current year profitability though, it is found to be positive. This may be an indication of low retention ratio to finance the growth potential of DBMs.

Contrary to our expectation, board diligence exert significant negative influence on profitability with a t-value of (-2.153279) which implies that increase in board meetings frequency will significantly reduce profitability. This finding aligns with Johl et al. (2013) which indicates that increase in board meetings frequency amounts to wasting of hard earned productive resources on 


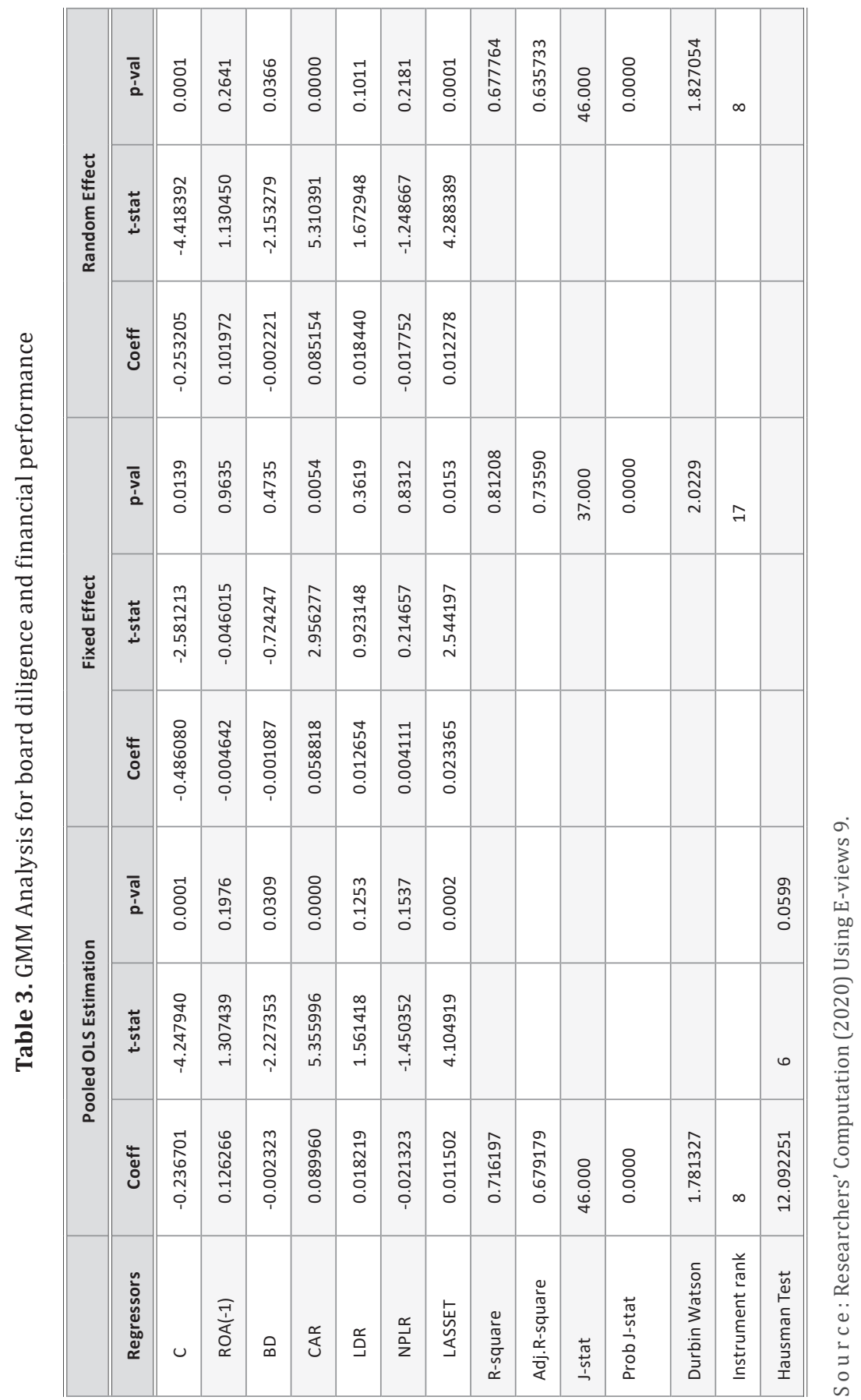


unproductive activities. It is therefore imperative for banks to hold optimum meetings as too much board meetings frequency could lead to wasting quality time and efforts (Ilaboya \& Obaretin, 2015). This outcome is in line with that of Hanh et al. (2018); Johl, Kaur and Cooper (2015); Akpan (2015) who found significant negative effect of board meetings on profitability while it contradicts findings by Ilaboya and Obaretin (2015) that found positive but insignificant impact of board meetings on profitability. Thus, the null hypothesis $\mathrm{H}_{01}$ that board diligence has no significant effect on financial performance of Nigerian DBMs is rejected.

In an attempt to avoid spurious result, other variables outside board meetings such as capital adequacy, loan to deposit ratio, non-performing loan ratio and bank size were introduced as control variables. Capital adequacy shows significant positive effect on profitability with a t-value of 5.310391.This means that banks' capital strength is a significant driver of profitability. This finding corroborates that of Sanyaolu et al. (2019). The implication of this finding according to Sanyaolu et al. (2019) may be due to the fact that capital adequacy may afford banks the opportunity of having sufficient fund to finance loan requests of customers and as well, being able to invest in new technology that reduces operational cost.

We found direct but no significant influence of liquidity on profitability. This means that liquidity ratio is not an important driver of profitability in the $\mathrm{Ni}$ gerian DBMs. This outcome is in disagreement with that of Bagh, Razzaq, Azad, Liaqat and Khan (2017) that found direct and significant effect of liquidity ratio on profitability.

Non-performing loan exert negative but no significant influence on profitability. This is consistent with our a priori expectation as non-performing loan is written off of profit and therefore, has tendency of reducing profitability. This outcome is however at variance with that of Annor and Obeng (2017) that found positive significant influence of non-performing loan on profitability.

Size positively and significantly affects profitability. This is also in line with our expectation as larger banks may enjoy economies of scale that reduce average cost of operation and boost profitability. This is consistent with the finding of Rahman, Hamid and Khan (2015) that show that size is an important driver of profitability. 


\section{DISCUSSION AND CONCLUSION}

The study examines the effect of board diligence on financial performance of 10 selected listed DBMs from 2012 to 2018 using GMM. The major finding is that board diligence has significant negative effect on financial performance measured by return on asset. This finding is supported by those of Hanh et al. (2018); Johl et al. (2015); Akpan (2015) that reported significant negative effect of board diligence on profitability. As to the control variables, only two variables- capital adequacy ratio and bank size exert positive significant influence on profitability, while loan to deposit ratio (liquidity ratio) and non-performing loan ratio were not found to be significant.

Empirical investigations have mainly focused on corporate governance and profitability in general, with very few studies that specifically addressed the issue of board diligence and profitability of Nigerian Deposit Money Banks. This study therefore examines the effect of board diligence on financial performance of Nigerian DBMs from dynamic perspective. The study found evidence for board diligence exerting negative but significant effect on profitability. This finding could be linked to the fact that frequency of board meetings could lead to diversion of management times and efforts to unproductive activities and, as well as diverting firm scarce resources on irrelevant and unproductive activities such as payment of high travelling and seating allowance to directors on the board, and as well as other associated costs of such meetings. Our study therefore recommends that quality of board meetings should be given priority and not the number of times such meetings are held. Also, important issues that are likely to translate to improved financial performance and maximization of shareholders wealth should be prioritized.

Another dimension to the finding of this study has to do with the quality of boards in the sector under focus. Issues such as board diversity, calibre of board members and the relevance of their experience are germane to the quality of board decisions in their meetings. How much of impact board decisions can have on company's financial performance is a function of members' understanding of the operational issues relating to their company's business. This also has to do with quality of board decisions particularly relating to operational and strategic issues affecting the business. Banking business in Nigeria appears so volatile with lots of inherent challenges such as inconsistency in government and regulatory policies, weak corporate governance regulations, 
endemic corrupt practices among others. Definitely this type of environment will require more than diligent boards for results. Experienced board members, with diversity of gender, background among others are anticipated.

As applicable on all studies, it is important to emphasize that our study has its own limitations. First, we examined board diligence and financial performance of Nigerian DBMs, future researchers can extend the scope by focusing on the non-financial sectors and other non-bank financial institutions. Also, inclusion of variables such as ownership structure, audit committee meetings in future studies may produce better opportunity for generalization.

\section{REFERENCES}

Akpan, E.O. (2015). Corporate board meetings and companies performance: Empirical evidence from Nigerian quoted companies. Global Journal of Commerce \& Management Perspective, 4(1), 75-82.

Al-Daoud, K.I., Saidin, S.Z., \& Abidin, S. (2016). Board meetings and firm performance: Evidence from the Ammn Stock Exchange. Corporate Board: Role, Duties \& Composition, 12(2), 6-11. http://dx.doi.org/10.22495/cbv12i2art1.

Amran, N.A. (2011). Corporate governance mechanisms and company performance: Evidence from Malaysia Company. International Review of Business Research Papers, $7(6), 101-114$.

Annor, E.S., \& Obeng, F.S. (2017). Impact of credit risk management on the profitability of selected commercial banks listed on the Ghana stock exchange. Journal of Economics, Management and Trade, 20(2), 1-10.

Araoye, F.E., \& Olatunji, T.E. (2019). Board meetings and financial performance of Insurance companies in Nigeria. European Journal of Accounting, Auditing and Finance Research, 7(9), 1-16.

Bagh, T., Razzaq, S., Azad, T., Liaqat, I., \& Khan, M.A. (2017). The causative impact of liquidity management on profitability of banks in Pakistan: An empirical investigation. International Journal of Academic Research in Economics and Management Sciences, 6(3), 153-170. http://dx.doi.org/10.6007/IJAREMS/v6-i3/3151.

Conger, J.A., Finegold, D., \& Lawler III, E.E. (1998). Appraising boardroom performance. Harvard Business Review, 76(1), 136-148.

Eluyela, D.F., Akintimehin, O.O., Okere, W., Ozordi, E., Osuma, G.O., Ilogho, S.O., \& Oladipo, O.A. (2018). Board meeting frequency and firm performance: examining the nexus in Nigerian deposit money banks. Heliyon, 4(10), 1-15. http://dx.doi.org/10.1016/j. heliyon.2018.e00850.

Elyasiani, E., \& Zhang, L. (2015). Bank holding company performance, risk, and busy board of directors. Journal of Banking \& Finance, 60, 239-251. http://dx.doi. org/10.1016/j.jbankfin.2015.08.022. 
Faleye, O., \& Krishnan, K. (2017). Risky lending: does bank corporate governance matter? Journal of Banking \& Finance, 83, 57-69. http://dx.doi.org/10.1016/j.jbankfin.2017.06.011.

Gatsi,J.G., Gadzo, S.G., \& Akoto, R.K. (2013).Degree of financial and operating leverage and profitability of insurance firms in Ghana. Canadian International Business and Management, 7(2), 57-65. http://dx.doi.org/10.3968/j.ibm.1923842820130702.1060.

Hanh, L.T.M., Ting, I.W.K., Kweh, Q.L., \& Hoanh, L.T.H. (2018). Board meetings frequency and finance performance: A case of listed firms in Vietnam. International Journal of Business and Society, 19(2), 464-472.

Ilaboya, O.J., \& Obaretin, O. (2015). Board characteristics and firm performance: Evidence from Nigerian quoted companies. Academic Journal of Interdisciplinary Studies, 4(1), 4-11. http://dx.doi.org/10.5901/mjss.2015.v4n1p283.

Ilaboya, O.J. (2008). Advanced Financial Accounting. Benin City: Midex Publishing.

Irshad, R., \& Ali, M. (2015). Board effectiveness, ownership structure and corporate performance: Evidence from Pakistan. Journal of Business Studies Quarterly,7(2), 46-61.

Jensen, M.C. (1993). The modern industrial revolution, exit, and the failure of internal control systems. Journal of Finance, 48(3), 831-880. http://dx.doi. org/10.1111/j.1540-6261.1993.tb04022.x.

Johl, S.K., Johl, S K., Subramaniam, N., \& Cooper, B. (2013). Internal audit function, board quality and financial reporting quality: Evidence from Malaysia. Managerial Auditing Journal, 28(9), 780-814.

Johl, S.K., Kaur, S., \& Cooper, B.J. (2015). Board characteristics and firm performance: evidence from Malaysian public listed firms. Journal of Economics, Business and Management, 3(2), 239-243. http://dx.doi.org/10.7763/JOEBM.2015.V3.187.

Kakanda, M.M., Bello, A.B., \& Abaa, M. (2016). Effect of capital structure on the performance of listed consumer goods companies in Nigeria. Research Journal of Finance and Accounting, 7(8), 211-219.

Körner, T. (2017). Board Accountability and Risk Taking in Banking: Evidence from a Quasi-Experiment. Journal of Financial Services Research,52(3), 155-190. http:// dx.doi.org/10.2139/ssrn.1996520.

Kress, J.C. (2018). Board to death: how busy directors could cause the next financial crisis. Boston College Law Review, 59, 877-929.

Lipton, M., \& Lorsch, J. (1992). A modest proposal for improved corporate governance. The Business Lawyer, 48(1), 59-77.

Marn, J.T.K., \& Romuald, D.F. (2012). The impact of corporate governance mechanism and corporate performance: a study of listed companies in Malaysia. Journal for the Advancement of Science and Arts, 3(1), 31-45.

Ntim, C., \& Osei, K.A. (2011).The impact of corporate board meetings on corporate performance in South Africa. African Review of Economics and Finance, 2(2), 83-103.

Oyedokun, G.O. (2019). Board characteristics and financial performance of commercial banks in Nigeria. Accounting and Taxation Review, 3(2), 31-48. 
Oyerinde, A.A. (2014). Corporate governance and bank performance in Nigeria: Further evidence from Nigeria. International Journal of Business and Management, 9(8), 133-139. http://dx.doi.org/10.5539/ijbm.v9n8p133.

Rahman, M.M., Hamid, K., \& Khan, A. (2015). Determinants of bank profitability: Empirical evidence from Bangladesh. International Journal of Business and Management, 10(8), 135-150. http://dx.doi.org/10.5539/ijbm.v10n8p135.

Sanyaolu, W.A., Shiyanbola, T.T., Gbadebo, G.T., \& Makinde A.B. (2019). Determinants of profitability of Nigerian banks. Economic Review. Journal of Economics and Business, 17(1), 47-62.

Taghizadeh, M., \& Saremi, S. (2013). Board of directors and firms performance: Evidence from Malaysian public listed firm. International Proceedings of Economics Development and Research, 59(37), 178-182.

Umar, A.I., \& Sani, D. (2020). Effect of corporate governance on the performance of listed deposit money banks in Nigeria. Science Journal of Business and Management, 8(1), 35-40. http://dx.doi.org/10.11648/j.sjbm.20200801.15.

Urhoghide, R.0.0, \& Omolaye, K.E. (2017). Effect of corporate governance on financial performance of quoted oil and gas in Nigeria. International Journal of Business and Social Science, 8(7), 114-124.

Vafeas, N. (1999). Board meeting frequency and firm performance. Journal of Financial Economics, 53(1), 113-42. 


\section{Appendix}

Table 1. List of sampled Banks

\begin{tabular}{|c|c|}
\hline \hline S/N & Name of Banks \\
\hline \hline 1 & GT Bank Plc. \\
\hline 2 & UBA Plc \\
\hline 3 & Access Bank Plc \\
\hline 4 & Zenith Bank Plc \\
\hline 5 & First Bank Plc \\
\hline 6 & Sterling Bank Plc \\
\hline 7 & Union Bank Plc \\
\hline 8 & Fidelity Bank Plc \\
\hline 9 & Wema Bank Plc \\
\hline 10 & Unity Bank Plc \\
\hline \hline
\end{tabular}

S o u r c e : authors' compilation (2020). 